\title{
Heterosexual transmission of hepatitis B virus: A public health perspective
}

JEAN ROBERT, MD, MSC, CSPQ, FRCPC

J RoBerT. Heterosexual transmission of hepatitis B virus: A public health perspective. Can J Infect Dis 1991;2(Suppl A):23A-26A. Given the objectives of the medical aspects of public health, the "heterosexual transmission' approach may be restrictive and too conventional as it considers transmission only through two individuals of different sexes and only by peno-vaginal penetration, to the exclusion of all other sexual activities. Bloodborne disease transmission in intravenous drug users must be considered as well as anal transmission of this disease. Three sine qua non conditions must be met before public health interventions are initiated: the disease agent must be known or presumed; a causal relationship must exist between the agent and disease; and the proposed intervention must be both pertinent and effective. The first two conditions have been established in the case of hepatitis B virus infection. The latter condition, however, has proven difficult to fulfill. It must be determined whether the approach of immunizing all infants, drug addicts and prostitutes is cost effective and accepted by a moral society. Consideration must be given to all possible modes of transmission in order to develop an effective public health strategy to combat hepatitis B.

Key Words: Hepatitis B; Heterosexual transmission; Public health

\section{La transmission hétérosexuelle du virus de l'hépatite B: Une perspective de santé publique}

RESUME: Compte tenu des objectif́s médicaux de santé publique, s'en tenir à la transmission hétérosexuelle du virus de l'hépatite $\mathrm{B}$ pourrait être une approche trop restrictive et trop conventionnelle vu qu'elle n'envisage que les rapports génitaux survenant entre deux personnes de sexes opposés. à l'exclusion de toutes autres activités sexuelles. Or il faut tenir compte de la transmission de la maladie par voie intraveineuse chez les toxicomanes, et de la dissémination par voie anale. Il faut remplir trois conditions indispensables avant de lancer toute initiative de santé publique: l'agent pathologique doit être connu ou présumé; une relation causale doit exister entre lagent et la maladie; l'intervention proposée doit ètre à la fois pertinente et efficace. Les deux premières conditions sont établies dans le cas de l'infection par le virus de l'hépatite $B$. La dernière s'est toutefois avérêe difficile. Il faut déterminer si une campagne de vaccination visant tous les enfants, les toxicomanes et les prostitué(c)s serait rentable et acceptée par une société morale. On doit tenir compte de tous les modes pussibles de transmission pour pouvoir êtablir une stratégie de santé publique efficace pour combattre l'hépatite $B$.

Chief, Public Health Department, Hopital St-Luc, Clinical Associate Professor, Faculty of Medicine, Universitė de Montréal. Montréal, Québec

Correspondence and reprints: DrJ Robert. Hopital St-Luc, 1001. rue St Denis, Montréal, Guébec H2X 3H9 
T HE IMPORTANCE OF HEPATITIS B VIRUS INFECTION, its repercussions and global distribution according to three endemic levels are universally recognized. No one questions the merits of vaccines or vaccination programs as a primary (ie, before exposure) or post primary (ie, after exposure) preventive measure (1). And yet, we have failed to control and eventually eradicate this infection.

Given the objectives of the medical aspects of public health, the 'heterosexual transmission' approach may be restrictive and too conventional. It is restrictive in the sense that it only considers transmission between two individuals of different sexes during sexual intercourse, and conventional because it only considers transmission through peno-vaginal penetration, to the exclusion of other sexual acts.

\section{PRINCIPLES OF PUBLIC HEALTH}

Public health is defined as the art of protecting and promoting health, ie, the physical, mental, environmental and social well-being of populations without excluding the health of the individual (2). This art calls upon several sciences, notably microbiology, physiology, pharmacology, psychology, sociology, economics and epidemiology. The art of public health is practised by preventing one or several diseases under the following three sine qua non conditions: the disease agent must be known or presumed; a causal relationship must exist between the agent and disease; and the proposed intervention must be both pertinent and effective. If one of these conditions is not met, intervention is often in vain and sometimes detrimental and thus would not fall within the realm of public health.

A more precise definition of public health requires an understanding of the notion of complementarity, which is not always obvious, between curative and preventive medicine. In curative medicine, the patient, who initiates the proceedings with the physician, is considered ill until there is evidence to the contrary. Intervention to restore health is then undertaken on an individual level. Abdominal pain leading to the diagnosis of appendicitis and subsequent surgical treatment is such an example. In preventive medicine, the physician initiates the proceedings. Patients are considered healthy unless evidence suggests otherwise and intervention is undertaken at the group level. One example is routine vaccination against measles at 12 months. In Québec, articles 16.1 to 16.7 (inclusive) of the Public Health Act $(3,4)$ recognize the principle of the common good and agree to provide compensation for the exceedingly rare but serious complications that may arise in individuals. It must also be borne in mind that the scope of public health care includes psychosocial reactions.

\section{A NONSELECTIVE VIRUS}

In 'high and average endemic' areas, universal vaccination of all children is accepted in principle as the best primary measure of preventive care (5). In children, infection occurs early (vertical and horizontal transmission) and morbidity and mortality rates are high. Fortunately, children are easier to reach through the expanded program on primary immunization. Since the virus in children is not transmitted through direct sexual contact, children may be viewed as innocent victims. In this context, universal vaccination of children is introduced before or soon after contact with the infective agent, without taking into account the group's ultimate sexual orientation, sexual behaviour or drug use habits. In matters of public health, as in other areas, decisions are easier to make when issues such as sexuality or drug addiction - referred to euphemistically as behaviour and lifestyle - are not involved.

With respect to hepatitis $B$ virus infection, hepatitis $B$ virus is the sole biological aggressor implicated in a serious pathological process. Fortunately, a vaccine is available which can be administered at a pertinent time, namely, before or shortly after contact with the source of the infection. Hence, the three sine qua non conditions are satisfied.

In 'low endemic' areas such as Canada, the situation is more complex and problematic. Viral transmission is more common among adolescents and young adults primarily through sexual and blood contacts than among infants or at birth. In this case, a second aggressor exists: the 'curse' or 'punishment' for acts deemed reprehensible by a society which imposes a certain morality. Thus, one is confronted with two epidemic situations with two aggressors: the biological infectious virus and the circumstantial event of possible transmission. Without the virus, there can be no infection. Circumstantial events alone such as prostitution. drug addiction and male or female (hetero-, bi- or homo-) sexual practices, cannot cause hepatitis B.

\section{TRANSMISSION IN MALE OR FEMALE HETEROSEXUALS}

There has been a reported decrease in the relative number of hepatitis $B$ virus infections in the adult male homosexual population (not determined in female homosexuals) countered by a disturbing relative increase among male and female heterosexuals. It must be recognized that this finding is not due to the success of any 
routine vaccination policy. Indeed, the male homosexual community has taught an important lesson in public health. It has taken upon itself, as in the case of the AIDS epidemic caused by the HIV virus, to protect or change certain circumstantial events. This has produced indirectly a beneficial effect on hepatitis B virus, thanks to the intervention of persons not accountable to public health departments.

In the early 1980s, the committee responsible for formulating a selective program to provide the hepatitis $B$ virus vaccine free of charge chose the following four target groups: infants born to infected mothers; patients undergoing long term blood treatment (hemophiliacs, thalassemia sufferers, hemodialysis patients); household or family contacts of carriers; and health care personnel (6). These were chosen from a list of about 10 target groups ranging from infants born to infected mothers to the general population, including, among others, the incarcerated, drug addicts, male homosexuals, prostitutes and migrants.

For newborn babies and patients on blood therapy the reasoning was simple: obvious biological justification, noble social value, and anticipated low number of people affected (and, therefore, relatively low cost). Despite their numbers, health care personnel ranked high in terms of medicalsocial and professional standing, although from a biological viewpoint they were at a disadvantage. Household members (ie, those residing in the same dwelling) or family contacts of carriers were defined as 'individuals (spouses and children) who have intimate contact with a carrier within the family'. Such a definition sparked a lively debate as to what constitutes a family. For example, does this include the common-law spouse, the biological children of the husband and wife, more than two spouses, and spouses of the same sex? This matter was left to be resolved by public health officers who, as heads of public health departments, would have to use their own discretion and draw funds from their own budgets.

The health of the budget has sometimes taken precedence over that of the target population. The other groups were not included in the policy due to the view that they are already a financial burden on society and are present in large numbers. Consequently, 80 to $85 \%$ of hepatitis B virus vaccine doses have been administered to health care workers, despite an infection rate just slightly above that of the general population.

\section{THE DILEMMA}

For the person in charge of public health, the ambiguity is enormous initially and the temptation overwhelming to pursue two priorities at the same time: to halt the spread of hepatitis B virus and to ease the sense of evil and punishment. Only one must be chosen, however, and the other taken into consideration.

Human sexuality is multilingual (7) as indicated by the Star of Venus (8) whose five points intersect and touch autologous and heterologous anatomical sites. No one can say whether coitus (9). sodomy, fellatio, cunnilingus, anilingus, masturbation, tribadism or kissing are of themselves homosexual, heterosexual or bisexual modes of transmission. Sexologists Kinsey (10), Hite (11), Masters and Johnson (12) and many others, have widely demonstrated the multivalent nature of human beings and have also shown that our closed and definitive classification of sexual orientation is simply theoretical and sometimes not in keeping with reality.

More consideration should be given to the many female heterosexual prostitutes who live with women longing to be mothers and to the number of their male customers who fantasize about anal penetration and pay double not to use a condom. Consideration should also be given to the number of male and female escort agencies and massage parlours that cater to business women. It should be recognized that $90 \%$ of the men who visit male prostitutes are married and, hence, are living socially and officially as heterosexuals. Furthermore, some people find prostitution to be the most profitable way to pay for drugs, which in turn might be considered necessary for selling one's body.

Feeling uncomfortable about such forceful in1ages is indicative of an ignorance and inability to come to terms intelligently with human sexuality within the context of STDs, including hepatitis B. Over the past decades, control of this disease has regrettably failed, despite the availability of penicillin and other antibiotics, new microbiological screening techniques, and antihepatitis B virus vaccination programs.

\section{THE SOLUTION}

The only solution for the control and eventual eradication of hepatitis B, even in 'low endemic' areas, is the universal vaccination of children. The adult subpopulations affected by hepatitis $B$ virus and certain vertical and horizontal modes of hepatitis $\mathrm{B}$ virus transmission are known. The associated risks of hepatitis B virus infection can be assessed to some extent. The potential for transmission through such vehicles as saliva, sperm, menstrual and vaginal secretions, urine, fecal matter and tears, however, is poorly understood (13). The biological vaccine product offers a solution, without waiting for the advent of adoles- 
cence, by banking on future contact with the circulating virus to serve as a booster in "average and high endemic' areas or in situations of high professional exposure (personal communication). Fear of being accused of promoting sexuality or drug addiction has driven the health care sector to practise 'postvention', ie, intervening after infection, instead of prevention. This attitude only serves to ease consciences rather than benefiting the health of patients. Sex and drugs are not waiting for promotion. Young people are already confronted with them from the mean age of 12 years $( \pm 4)$.

\section{AT WHAT COST?}

For two years now, pharmaceutical manufacturers have said that they can produce a pediatric vaccine for under $\$ 1$ a dose (14) on the condition, however, that they receive a firm worldwide order of 200 million doses annually. But international public health agencies are waiting for a price announcement before they make any firm orders. What sort of financial compromise is society prepared to make in order to contribute to the worldwide eradication of a virus, without procrastinating, to protect travellers and missionaries indirectly and protect drug addicts, prosti-

\section{REFERENCES}

1. Andrê F-E. Prevention of transmission of hepatitis $B$ infection by sexual route. In: Piot P, André F-E, eds. Hepatitis B: A Sexually Transmitted Disease in Heterosexuals. Amsterdam: Elsevier Science Publishers, 1990:89.

2. Robert J. VIH et santê publique. In: Olivier C. 'Thomas R, eds. Le sidA, Un Nouveau Défi Mêdical. Montréal: L'Association des médecins de langue française du Canada, 1990:321.

3. Gourvernement du Québec. Loi sur la protection de la santé publique. 1985: LRQ c. P-35, art $16,1-16,7$.

4. Gouvernement du Québec. Réglement d'application de la Loi de la protection de la santé publique. 1987: art 233-58.

5. Kane M-A. Transmission of the hepatitis $B$ virus in areas of low endemicity. In: Piot P, André F-E, eds. Hepatitis B: A Sexually Transmitted Disease in Heterosexuals. Amsterdam: Elsevier Science Publishers, 1990:9.

6. Gouvernement du Québec, Ministère des Affaires sociales. 1983 Dircctive 1983-06. Vaccination contre l'hépatite B.

7. Dahan P, Moluch. Traité de Sexologie. Paris: tutes and all sexual beings directly? The inclusion of the antiwhooping cough component of the diphtheria-whooping cough-tetanus vaccine in 1946 was primarily due to its low cost. The same holds true for the antimumps component in the combined measles-german measles-mumps vaccine in 1976.

The rule that states that antihepatitis $B$ virus vaccination be given within 14 days after sexual contact with an infectious source may not be useful as it was established by simple analogy with immunoglobulins against hepatitis A virus. Furthermore, this rule would not benefit the patient who visits the doctor on day 15 or 16 .

\section{CONCLUSIONS}

A clearer vision of this health problem on the part of public health authorities and society in general might have led to the timely implementation of a selective, unbiased primary pre-exposure vaccination program for the youth of tomorrow who would be at risk. By default or elimination, we must now seriously consider a universal vaccination program against hepatitis $B$ in all children. The indirect effect of such a program will also benefit and protect those who escape vaccination.

Garanciêre, 1984.

8. Robert J. Comportements et gestes à risque. In: Morisset R, Pechère J-C, eds. Reconnaître, Comprendre, Traiter les MTS. Montréal et Paris: Édisem et Maloine, 1990:467.

9. Germain B, Langis P. Ia sexualitê : Regards actuels. Montrêal: Études Vivantes, 1990:331.

10. Kinsey AC, et al. Concepts of normality and abnormality in sexual behavior. In: Hoch PH, Zubin J, eds. Psychosexual Development in Health and Disease. New York: Grune and Stratton, 1949.

11. Hite S. Le Rapport Hite sur les Hommes. Paris: Robert Laffont, 1981.

12. Masters and Johnson. Les Perspectives Sexuelles. Paris: Éd Medis, 1980.

13. Judson F. Control of sexual transmission of hepatitis $B$ virus infections. In: Piot P. André F-E. eds. Hepatitis B: A Sexually Transmitted Disease in Heterosexuals. Amsterdam: Elsevier Science Publishers, 1990:101.

14. Vaccine (1990, 8-S): Proceedings of the International Conference on Prospects for Eradication of Hepatitis B Virus, Genève, 1989. Guildford: Butterworths, 1989. 


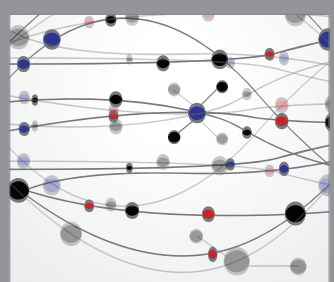

The Scientific World Journal
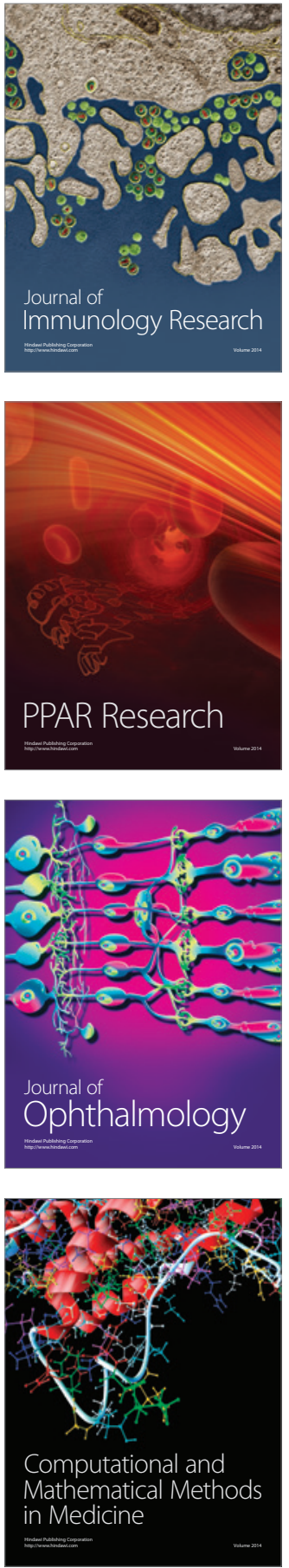

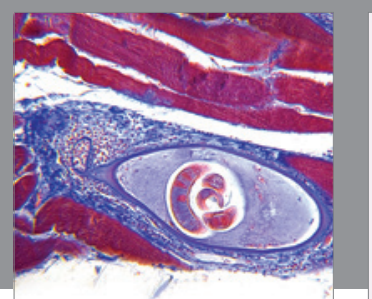

Gastroenterology Research and Practice

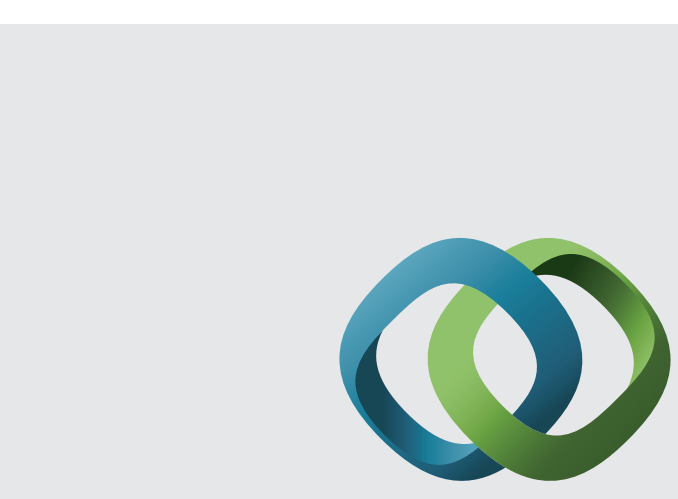

\section{Hindawi}

Submit your manuscripts at

http://www.hindawi.com
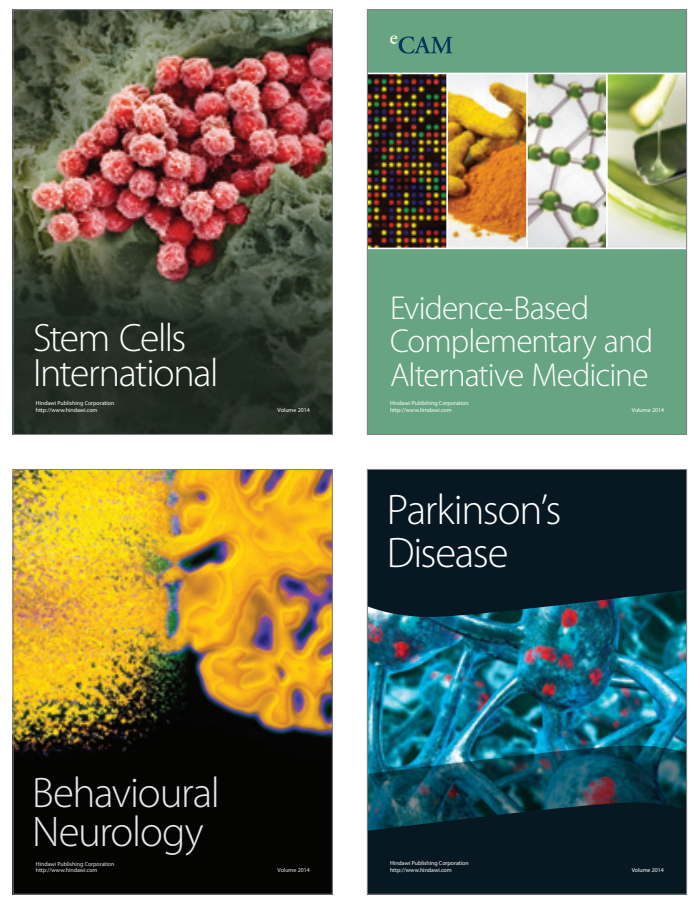
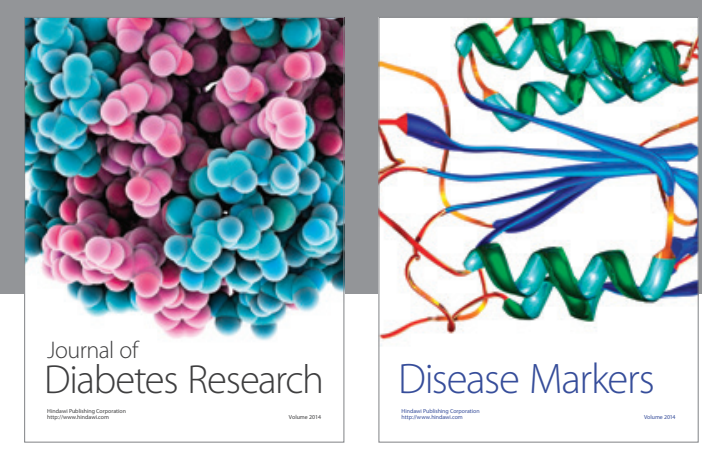

Disease Markers
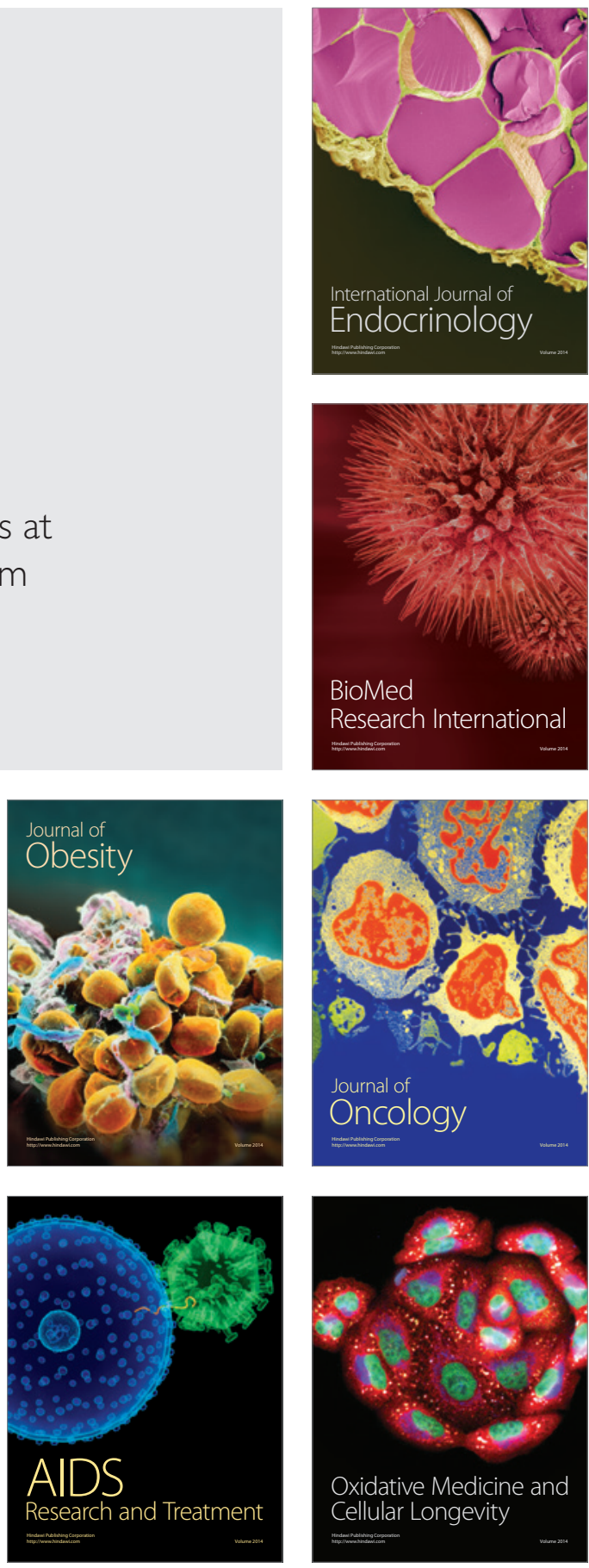